by Azidane Hind ${ }^{l *}$, Benmohammadi Ä̈cha ${ }^{1}$, Haddout Soufiane ${ }^{2}$, Hakkou Mounir ${ }^{3}$, Belrhaba Tarikl, Michel Boko ${ }^{4}$, and Magrane Bouchaib ${ }^{5}$

\title{
Evaluating the impacts of sea-level rise on the Moroccan coast: quantifying coastal erosion and inundation in a Atlantic allu- vial plain (Kenitra coastal)
}

\author{
${ }^{1}$ Department of Geology, Faculty of Sciences, Ibn Tofail University, B.P. 133, Kenitra, Morocco; *Corresponding author, E-mail: \\ hind.azidane@uit.ac.ma \\ ${ }^{2}$ Department of Physics, Faculty of Sciences, Ibn Tofail University, B.P. 133, Kenitra, Morocco \\ ${ }^{3}$ Department of Geology, Faculty of Science, University Mohammed V Agdal, Scientific Institute, B.P. 703, Rabat, Morocco \\ ${ }^{4}$ Laboratory of Climatology, National University of Benin, Cotonou, Benin \\ ${ }^{5}$ Ministry of Energy, Mines, Water and Environment, Water Service of Kenitra City, B.P. 203, 14000 Kenitra, Morocco
}

(Received: August 9, 2016; Revised accepted: June 12, 2017)

http://dx.doi.org/10.18814/epiiugs/2017/v40i4/017028

As part of a broad assessment of climate change impacts in Morocco, an assessment of vulnerability and adaptation of coastal zones to sea-level rise was conducted. The Kenitra coast is socio-economically vulnerable to accelerated sea-level rise, due to its low topography and its high ecological and touristic value. In this study, the effects of future relative sea-level were evaluated for the low alluvial plain Atlantic (Kenitra coastal). This study area is potentially subject to coastal flooding due to its very low topography and because it is affected by a considerable subsidence. Using a GIS-based inundation analysis; the evolution of erosion that occurred in the study area, the potential physical vulnerability to accelerated sea-level rise was investigated, and the most vulnerable socio-economic sectors were assessed. Results indicate that $35 \%$ of the areas will be lost by flooding. In addition, the coast is progressive and regressive with an average rate at minimum $(0.31 \mathrm{~m} /$ year $)$ and at maximum (-2.39 m/year). Such results may help decision-makers in the implementation of preventive management strategies in the most sensitive areas.

\section{Introduction}

The effects of climate change on the hydrological cycle in general and on water resources in particular are of high significance due to the fact that all natural and socioeconomic system critically depends on water. The direct impact of climate change can be variation and changing pattern of water resources availability and hydrological extreme events such as floods and droughts, with many indirect effects on agriculture, food and energy production and overall water infrastructure (Ebrahim et al., 2013; Azidane et al., 2016). On the other hand, within the last few decades, the atmospheric and sea surface temperatures have been rising and climates worldwide are changing (Musa et al., 2014). The increase in temperature is even affecting the biological, the chemical and the physical characteristics of the oceans. Sea-level rise, resulting from thermal expansion of ocean waters and increased melting of glaciers and ice caps, is one of the most apparent and widespread consequences of climate change (Nicholls, 2004; Dasgupta et al., 2007; Aucelli et al., 2016). This phenomenon has been taken into account in all the Assessment Reports published by the Intergovernmental Panel on Climate Change (IPCC, 2007, 2014). In the last one, different scenarios for the sea level in 2065 and 2100 are provided. The Intergovernmental Panel on Climate Change (IPCC) suggested a cumulative rise of 9-88 $\mathrm{cm}(0.9-8.8 \mathrm{~mm} /$ year $)$ by 2100 unless greenhouse gas (GHG) emissions are reduced (Demirkesen et al., 2008).

The sea-level rises on coastal areas including relevant interacting climate factors are affecting human and natural systems around the world. Indeed, global sea-level rise will lead to an increase in flood hazard in coastal regions (IPCC, 2007). And would increase the susceptibility of coastal populations for which there are various global and sub-global estimates (Bouwer et al., 2007). In addition, many coastal areas suffer from natural land subsidence due to a combination of glacial-isostatic adjustments (Peltier, 1998; Meckel et al., 2007), also human activities (Chatterjee et al., 2006; Nicholls et al., 2008). Given the scale of these problems, it is increasingly recognized that estimates of the vulnerability of cities are essential in the planning of adaptation measures (Aerts et al., 2009).

In Morocco, accelerated sea-level rise will intensify the stress, causing flooding of coastal lowlands, erosion of sandy beaches, and destruction of coastal wetlands. Therefore, sea-level rise has to be one of the main impacts of climate change on Morocco.

The present paper deals with the study of flooding risk due to sealevel rise in the Kenitra coastal plain, one of the widest plain in NorthernWestern Morocco. The study area is socio-economically vulnerable to accelerated sea-level rise and potentially prone to coastal flooding due to its very low topography. The main objectives of this contribution 
are: (1) Further developing a methodology for the rapid assessment of inundation mapping and erosion, (2) To assess the most vulnerable socio-economic sectors at risk.

Finally, the analysis carried out and the obtained results draw attention to the importance of a territorial management policy for the risk reduction or proposed some response strategy and adaptations for the sustainability of the Atlantic coastal region of Kenitra. In addition, recent development processing techniques and data gathering, including Geographic Information System (GIS), have helped to overcome this constraint.

\section{Study Area Description}

The Kenitra coastline (20 km long) is located on the Moroccan Atlantic coast (Fig. 1). It is a straight wave-dominated meso-tidal beach environment aligned about $30^{\circ}$ to the NS direction (Moussaid et al., 2015). This coast delimits the Atlantic continental shelf and the subsiding Gharb plain located at the junction between the stable Meseta domain to the south and the Rifian domain to the north.

The sandy beaches are mostly bordered by 5-20 m-high consolidated eolian dunes with the sediment consisting of medium sand rang- ing between 200 and $370 \mu \mathrm{m}$ (Madouni, 1997; Benmohammadi et al., 2007) and a gentle foreshore slope of 1-3\% (Moussaid et al., 2015). Beaches are interrupted by the Sebou tidal inlet formed by two walls that extend approximately $600 \mathrm{~m}$ seaward from the low tide level shoreline (Hakkou et al., 2011). The Sebou is the largest Moroccan river, draining approximately $40.000 \mathrm{~km}^{2}$, stretching about $614 \mathrm{~km}$ from its source in the middle Atlas Mountains to the Atlantic Ocean, which represents $6 \%$ of Morocco's total land area (Haddout et al., 2016a).

The Kenitra coastal is an exposed to high-energy wave traveling roughly from the NW sector. These are generated by W-E tracking subpolar, deep, low-pressure systems over the North Atlantic Ocean and are therefore strongly seasonally modulated. Substantially higher waves are observed during the December-March winter period (Moussaid et al., 2015). It is hypothesized that significant wave heights can reach 7-9 m during severe storms (Benmohammadi et al., 2007). The tide type is meso-diurnal (Haddout et al., 2016b; Haddout et al., 2017) with a tidal range of $2.3 \mathrm{~m}$ on average, which can vary from 0.97 to $3.11 \mathrm{~m}$ during neap-spring periods, respectively. Tide-induced currents on the continental shelf are of the order of $0.2-0.3 \mathrm{~m} / \mathrm{s}$ (Idrissi et al., 2004; Hakkou et al., 2011) with generally northward and southward currents during flow and ebb, respectively. Coastal currents, which

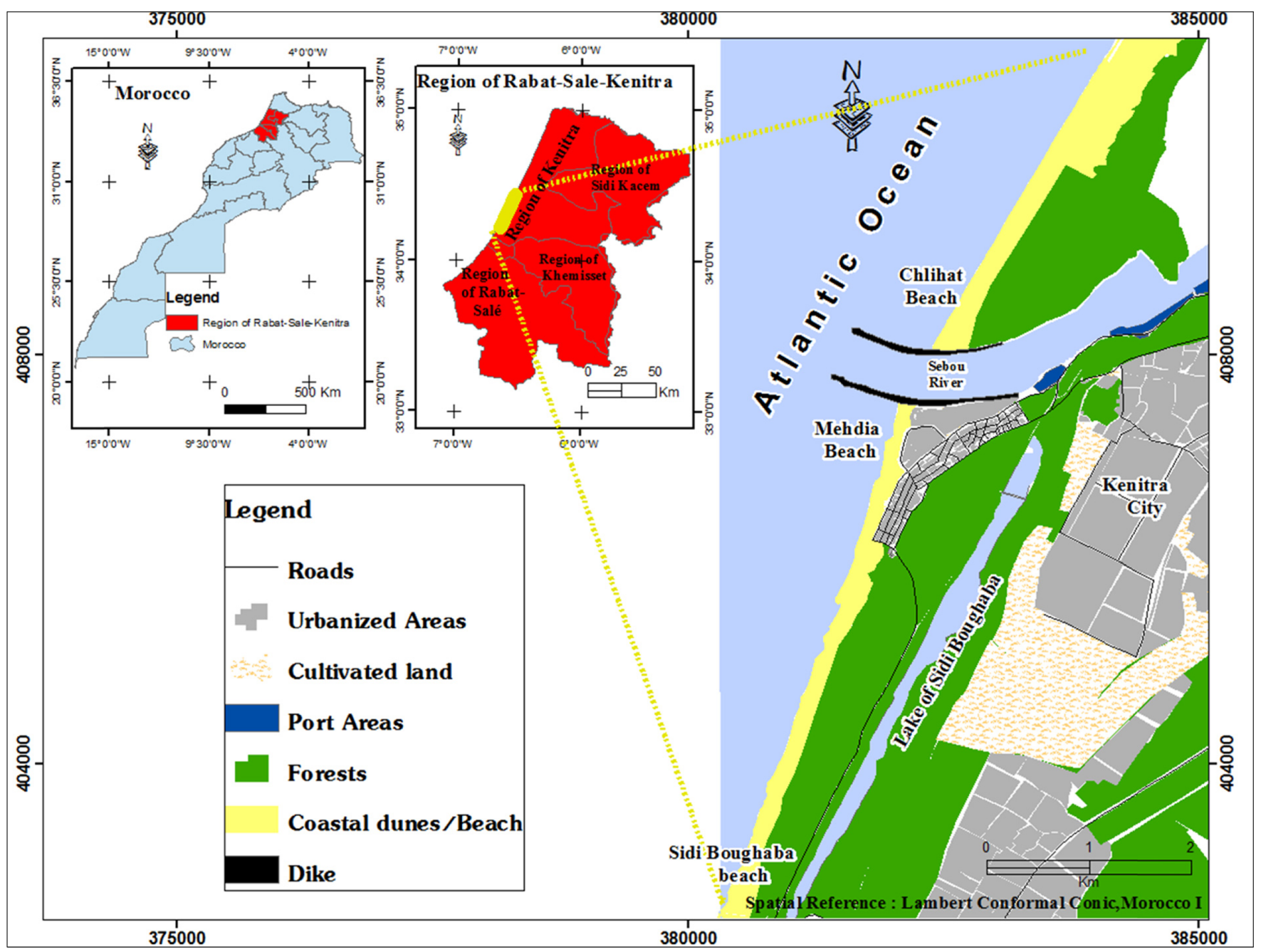

Figure 1. Location map of the study area. 
have been observed to be highly variable and dependent on seasons and the local bathymetry, are of the order of $0.1-0.5 \mathrm{~m} / \mathrm{s}$ (Idrissi et al., 2004; Hakkou et al., 2011). Prevailing winds are westerly (63\%), particularly during the winter period, with only scarce gale events, while persistent northeasterly trade winds are observed during summer (Mhamdi Alaoui et al., 2010).

\section{Materials and Methods}

Some methods have been implemented in order to achieve the objectives of the research. The overall approach followed in this study involves the use of sea level and wave height data to estimate the inundation level, a digital elevation model to generate the coastal inundation map, the aerial photo to generate the coastal erosion map.

\section{Morphology of the Study Area}

The morphology of the study area is illustrated using a digital elevation model (DEM) established for this reason. Technically, the creation of a DEM is done under multiple software among others, the ArcGIS software. Its elaboration requires digitalization work, cleaning contour lines and spot heights, and attribution altimeter values.

The Morphology of the study area is perfectly described in the study of (Aberkan, 1989). Morphologically, the principal sedimentary environments existing are; moved dune and consolidated dunes interrupted by the mouth of Sebou River (Fig. 2). Between the dune system and the sea, they develop the long beaches characterized by different slope and widths. The dune system exceeds $70 \mathrm{~km}$ of length and a width of 1 to $10 \mathrm{~km}$, which constitutes a barrier between the Gharb plain and the Atlantic Ocean. The sea and wind action are responsible to setting up the dune system.

This dune system that overcomes the coast protects this low-lying area against marine flooding. The current morphology of Kenitra is much influenced by the combined effects of coastal sedimentation and erosion, especially on the Mediterranean coast due to the sea-

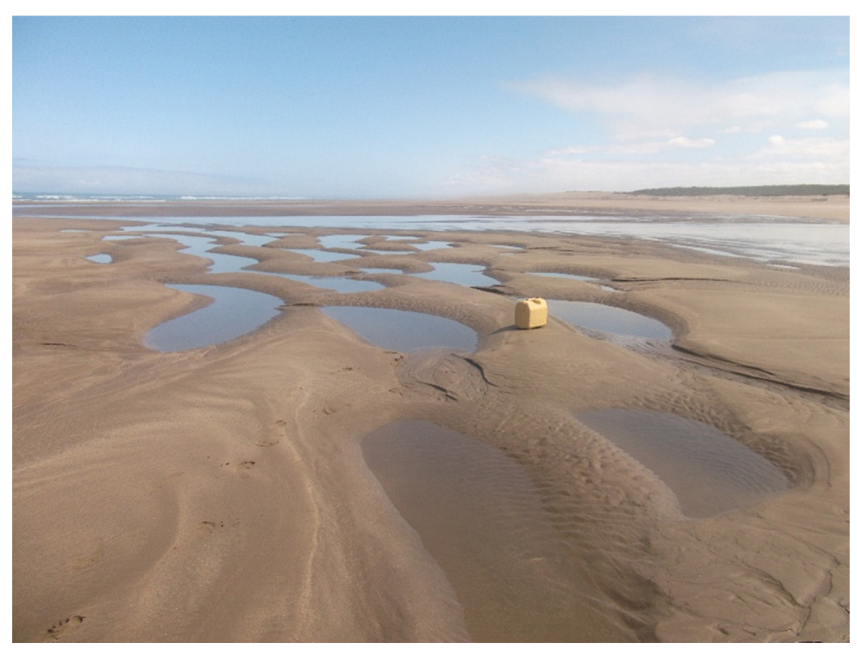

Figure 3. Mega ripples on the Chlihat beach.

sonal fluctuation of its sea level (Hakkou, 2012). This straight sandy beach, on good weather, develops the mega ripples visible in Mehdya beach and Chlihat beach (Fig. 3).

\section{Projection Global Relative Sea Level Rise}

The projections on the basis of all emission scenarios used indicate an increase in surface temperature during the next century (IPCC, 2014). It is very probable that the frequency and duration of heat waves will increase and extreme precipitation will become more intense and frequent in many regions. The oceans will continue to warm and acidify and the average sea-level to rise. The future change in ocean volume, caused by global warming and ice melting, has been evaluated by Intergovernmental Panel on Climate Change (IPCC, 2014) where different SLR scenarios have been provided. In this study, the mean values of RCP2.6 and RCP8.5 scenarios, that are respectively the best and the worst conditions, have been adopted for the 2065 and 2100 projections (Table 1).

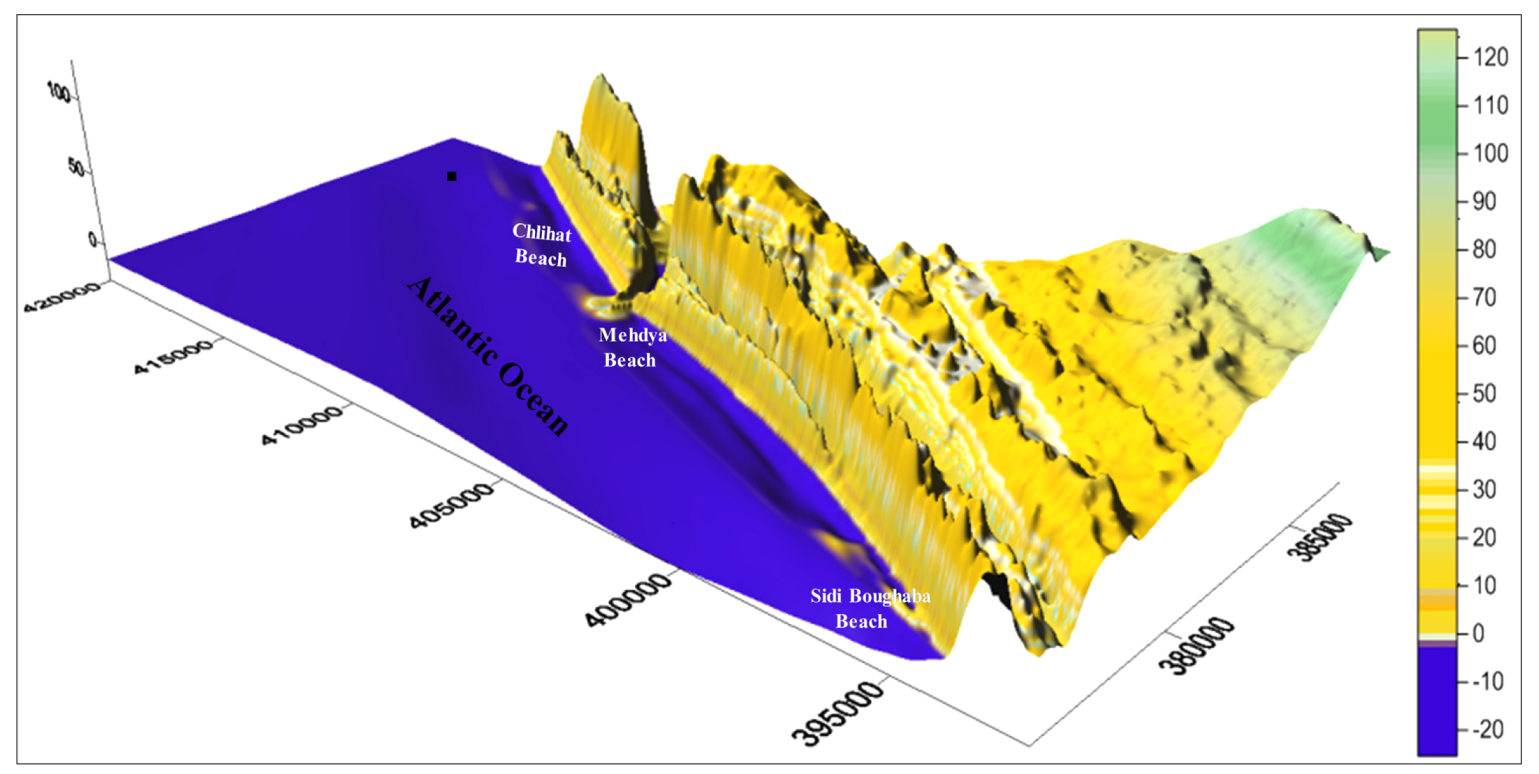

Figure 2. DEM of the study area showing morphological structures. 
Table 1. Sea level rise scenarios used in the study (based on data available from IPCC, 2014)

\begin{tabular}{|c|c|c|}
\hline Scenarios & Year & Sea Level rise $(\mathrm{m})$ \\
\hline \multirow{2}{*}{ IPCC RCP 2.6 } & $2014-2065$ & 0.30 \\
\cline { 2 - 3 } & $2065-2100$ & 0.45 \\
\hline \multirow{2}{*}{ IPCC RCP 8.5 } & $2014-2065$ & 0.40 \\
\cline { 2 - 3 } & $2065-2100$ & 0.74 \\
\hline
\end{tabular}

\section{Inundation Level Scenarios}

Empirical approaches were used to assess the inundation levels, using the equation of Hoozemans et al. (1993):

$$
I n_{\text {Lev }}=M H W+S+H T R+S P,
$$

where: $\operatorname{In}_{\mathrm{Lev}}$ is the inundation level; MHW the mean high water level; $\mathrm{S}$ is the relative sea-level rise; HTR the height of waves and SP the sea-level rise due to a lowering of the barometric pressure. The nearest tide station to the study area was at Sebou mouth $\left(34^{\circ} 16^{\prime} \mathrm{N}, 6^{\circ} 41^{\prime} \mathrm{W}\right)$, which has measurements that are available for this study. The database exploited for the analysis of the dynamics of the wave to broad and the shore of the sector of study was downloaded via NOAA site. They are data of the model of total vagueness WW3, which calculates on a grid covering the whole of the sphere, with a resolution of $1^{\circ}$ into North-South and of $1^{\circ} 15^{\prime}$ in East/West, the physical parameters of the swell (significant Height, period of peak and angle of incidence). The point of grid nearest to Gharb, is at the point $\mathrm{N} 34^{\circ} 00^{\prime} 00 \mathrm{E} 7^{\circ} 15^{\prime} 00$, located at $32 \mathrm{~km}$ of the shore (Hakkou et al., 2010). Hoozemans et al.
Table 2. The inundation levels in 2065 and 2100

\begin{tabular}{|c|c|c|}
\hline Scenarios & Year & Inundation levels (m) \\
\hline \multirow{2}{*}{ IPCC RCP 2.6 } & 2065 & 6.70 \\
\cline { 2 - 3 } & 2100 & 6.85 \\
\hline \multirow{2}{*}{ IPCC RCP 8.5 } & 2065 & 6.80 \\
\cline { 2 - 3 } & 2100 & 7.14 \\
\hline
\end{tabular}

(1993) define a risk zone as the land area between the coastline and the "maximum" design water level. This calculation indicates a preliminary extent of the area at risk of flooding.

The inundation levels were calculated using a mean value of high water-level (2.4 m); mean wave height (4 m) and for SLR (See Table 1). These values were related to the hydrographic zero. Table 2 shows the inundation levels calculated for 2065 and 2100.

\section{Coastal erosion assessment}

At present, the aerial photographs are the best documents reflecting the physiognomy of the coastline at any moment (Hakkou et al., 2010). Their exploitation allows visualizing trends and to quantify them, especially her progradation, her retrogradation or her stability on a relatively time scale. For this, the spatio-temporal evolution of the coastline of the Kenitra area over a period of 40 years using the aerial photographs of 1969, 1997 and 2009 is necessary (Fig. 4).

The treatment of these aerial photographs allows the mobility of the coastlineby exploiting a more appropriate model for studies of the coastline, namely DSAS (Digital Shoreline Analysis System). This study remains necessary for the forward management of coastal risks.

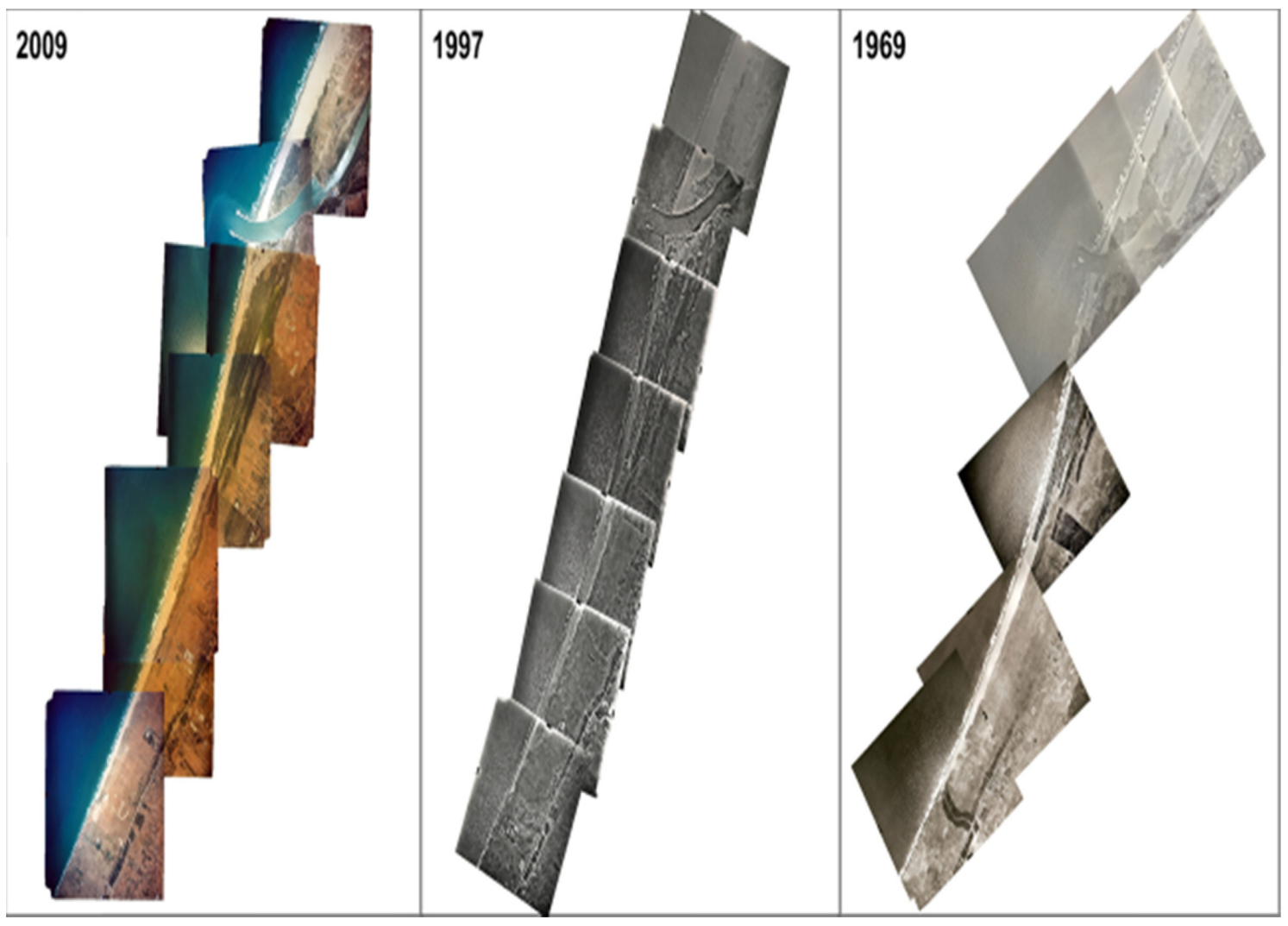

Figure 4. Mosaics images of the Kenitra coastline evolution. 
This study allows the decision-makers in the region and managers of the coastal area (service of state...) and users of this space (inhabitants, professionals of the sea ...) perceive their environment and risks. Thus, to take into account the future of sandy beaches by incorporating management plans into city management projects. And which allows coastal managers and planners to rapidly determine high-risk areas in the coastal zone. These aerial photographs mosaics made it possible to draw coastlines for each mission and to deduce the evolution of the shore.

\section{Results and Discussion}

In this section, we present and discuss the results for two sets of analyses. In the first, we present results pertaining to a scenarios inundation analysis. In the second section, we explore the morphology of three beaches and the methodology for the rapid assessment of coastal erosion.

\section{Inundation Scenarios}

Four inundation scenarios are described in Figures 5 and 6 . The most significant changes are the natural coastal defenses, such as dunes which have been destroyed. At the inundation level (6.7, 6.85,
6.8 and $7.14 \mathrm{~m}$ ); $35 \%$ of the total area would be flooded, including coastal dunes/beach, mouth of the Sebou, Lake of Sidi-Boughaba and tourism infrastructures located in Mehdya beach.

Even if some parts of the ecosystem of the Mehdya wet land are not destroyed, because those parts could adapt to sea-level-rise and move landwards, the species richness is likely to decrease, due to unfavourable new conditions where several plant communities and rare species would disappear. Indeed, loss of people living in the area at risk of flooding, as well as industrial infrastructures (Snoussi et al., 2009).

\section{Morphology and Coastal Erosion Assessment}

Through various physical processes the shoreline has been eroded and shaped and the landscape modified. Most shoreline changes are natural responses to these processes, either at a time scale of days (e.g., between tides) or of years (e.g., global climate change) (Barbosa, 2004).

\section{Chlihat sector morphology}

The beach stretches $4.5 \mathrm{~km}$. She has a very wide foreshore beach of $200 \mathrm{~m}$ and slope of $1 \%$ and its morphodynamics is therefore dissipative. The constitution of the DEM allowed describing the relief. Indeed, from the ocean to the continent, the relief evolves a white dune with an average height of $18 \mathrm{~m}$ (Fig. 7), followed landward two
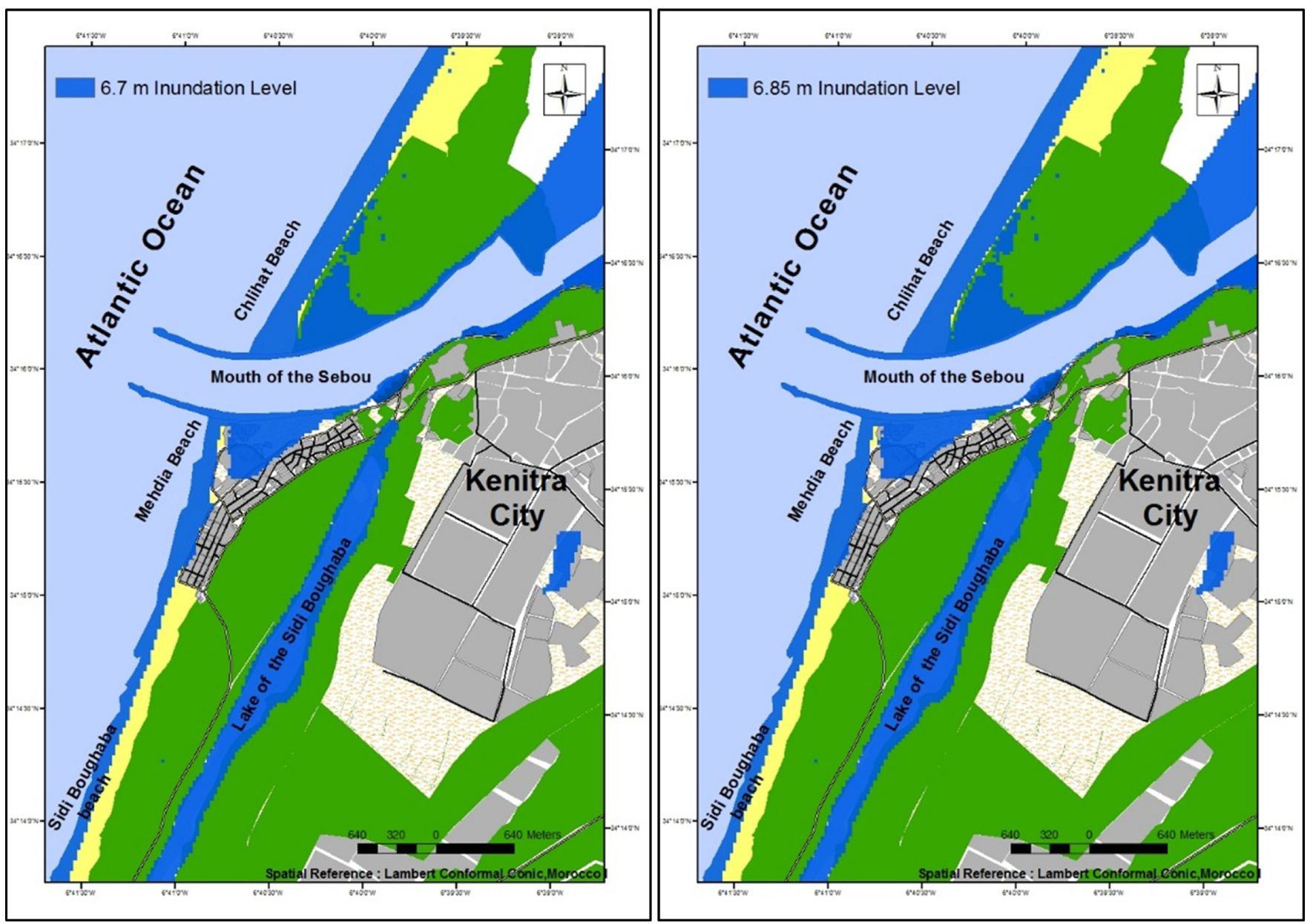

Figure 5. Land area vulnerable to flooding with inundation level scenario IPCC RCP $2.6(6.7 \mathrm{~m})$ in 2065 and (6.85 m) in 2100. 


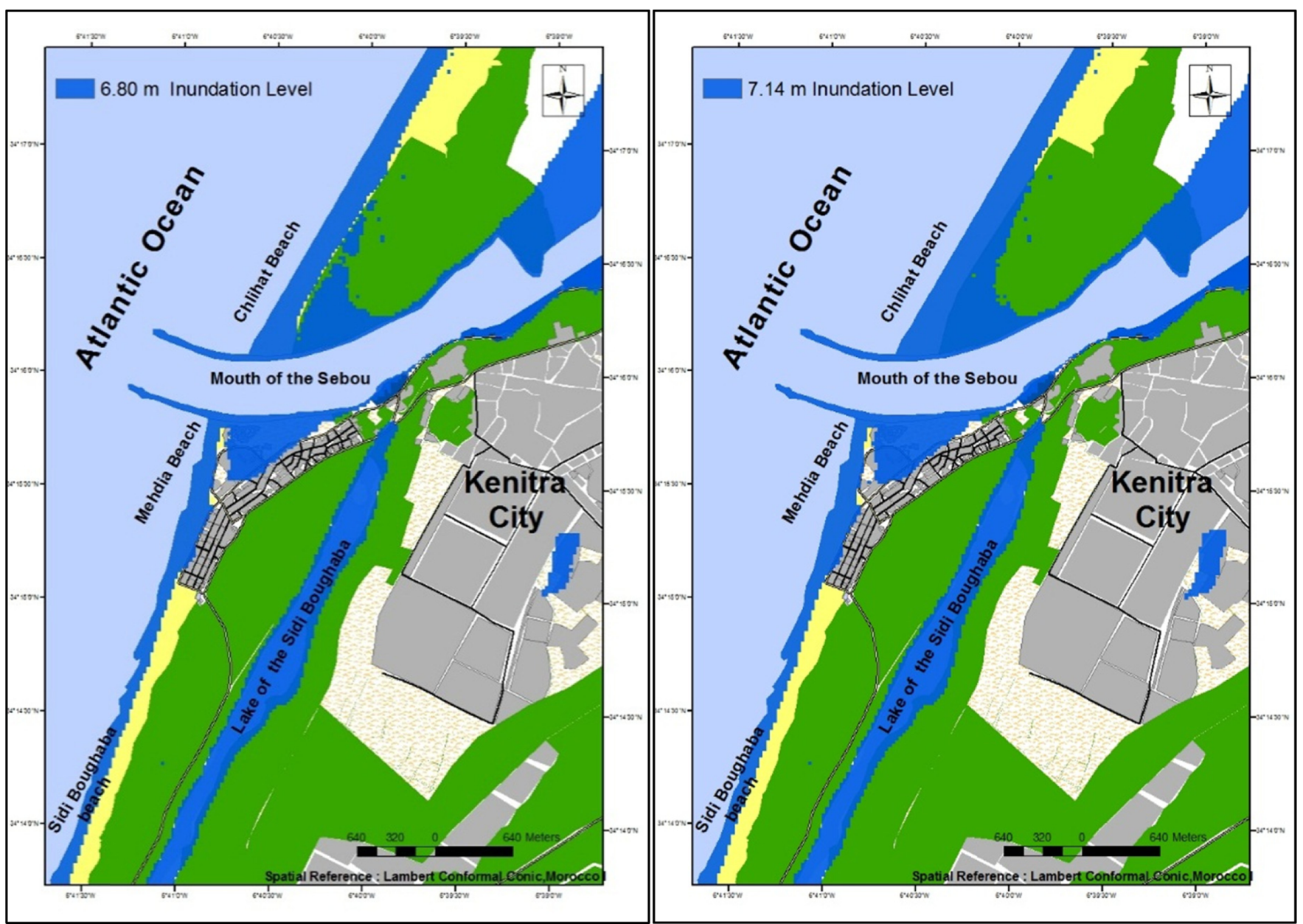

Figure 6. Land area vulnerable to flooding with inundation level scenario IPCC RCP8.5 (6.80 m) in 2065 and (7.14 m) in 2100.

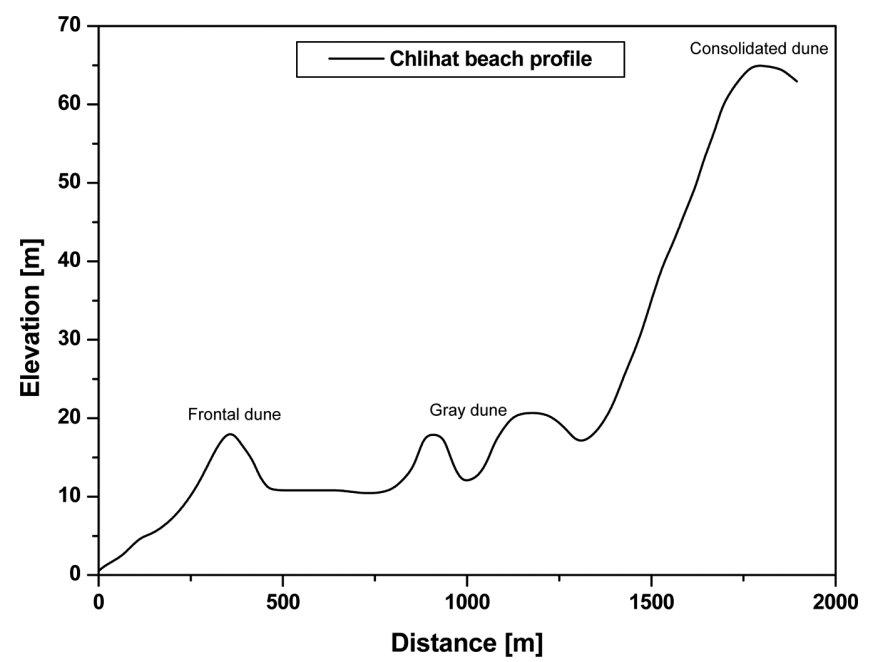

Figure 7. Elevation profile of the northern part of the Chlihat beach.

more dunes of the same height separated by an inter dune corridor. Further inland a consolidated dune with a height of over $60 \mathrm{~m}$ forms the end of the coastal plain. The dune in this sector has experienced the fixation efforts by the department of water and forests. The results were beneficial and the shrubs are sufficiently developed.

\section{Mehdya sector morphology}

The beach stretches $4 \mathrm{~km}$ south of the left shore of Sebou river. She presents a concave plane. The northern beach sector is protected by the south discarded of mouth of Sebou. The sandy beach has a foreshore less wide than Chlihat (100 m on average) and a moderate slope (2-3\%). According to Hakkou et al. (2010) and Hakkou (2012), the beach morphodynamic is intermediate type, close to dissipative. From the ocean to the continent, the coast is evolved. It was a beach with a large less than $100 \mathrm{~m}$, and its develops later to a high dune of $20 \mathrm{~m}$ that has been excavated to build the city of Mehdia, riding a gray dune of $25 \mathrm{~m}$. Followed by another high dune of $60 \mathrm{~m}$ separated by lake Sidi Boughaba (Fig. 8).

The urbanization of the municipality of Mehdia was built on the frontal dune. It cannot be shown here with great accuracy due to lack of contour and spot elevations on topographic maps used to establish a digital terrain model for the region.

\section{Sidi Boughaba sector morphology}

This sector starts from the southern end of the Corniche of Mehdia and extends to Taxi Beach. Field observations show that the foreshore has a width of $120 \mathrm{~m}$ during low spring tide, and a slope less than $3 \%$. From the ocean to the continent the beach has the same morphology like Mehdia. A white dune height of $25 \mathrm{~m}$ overlaps another gray dune, fixed (Fig. 9). Locally, we can observe berms taking trans- 


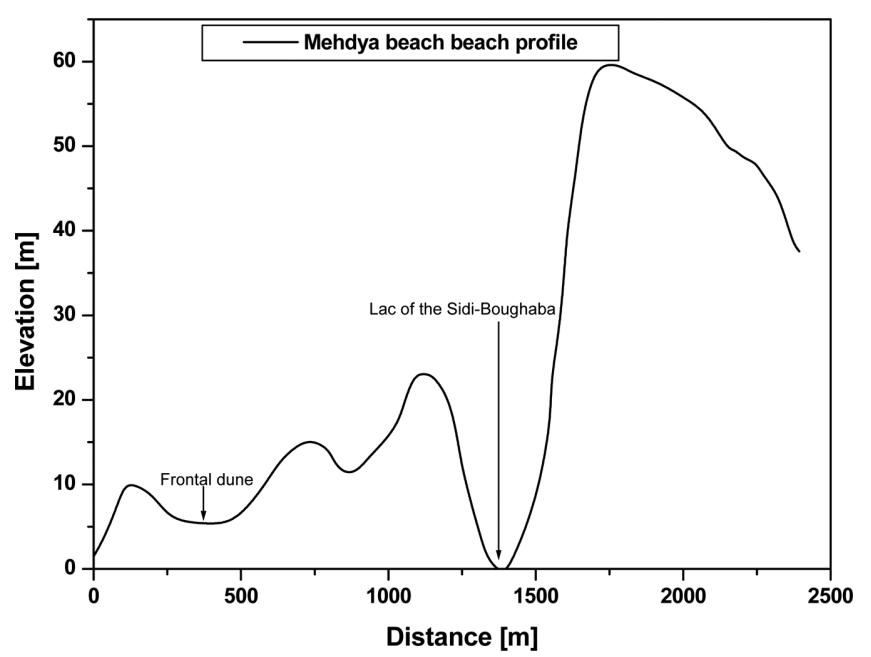

Figure 8. Elevation profile of the Mehdya beach.

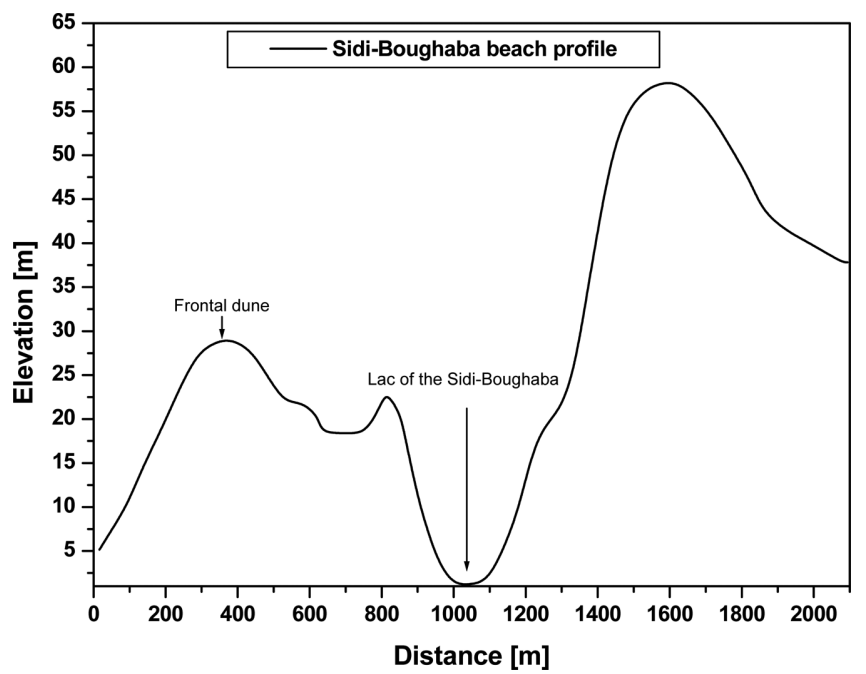

Figure 9. Elevation profile of the Sidi Boughaba Beach. verse forms that reflect an average mobility of the coastline.

\section{Coastal Erosion Assessment}

The results of semi-automatic calculation of the distances between the positions of the coast line identified on aerial photographs from 19691997 reveals a significant progradation of the beach that reached 3.41 $\mathrm{m} /$ year on average. The progradation of the beach is more important in the North. The more one moves south, the more the progradation rate decreases. Near the dike, it reaches $+2.94 \mathrm{~m} /$ year.

The summation of 40 years of mobility of the coastline from 1969 to 2009 reveals a prograding evolution to an average rate of $+1.96 \mathrm{~m} / \mathrm{year}$.

On Chlihat, Mehdya and Sidi Boughaba Beachs, the analysis results show an evolution of the coastline over two periods (Figs. 10 and 11):

- From 1969 to 1997: an alternating zones of erosion and accretion in the South bay where the beaches of Mehdya and the North SidiBoughaba suffered severe erosion compared to other beaches with an average rate of erosion for Mehdya $0.31 \mathrm{~m} /$ year.

- In the period from 1997 to 2009: coastal erosion is well established throughout the study area except for a few very limited areas. During this time the beach of Mehdya records a maximum erosion rate with an average order of $-2.39 \mathrm{~m} /$ year.

The values recorded in the period of 40 years (1969-2009) show a significant deterioration in the southern sector of Sebou river beaches, mainly at the beach of Mehdya and North Sidi-Boughaba. This finding challenges the coastal managers to pay more attention to this sector.

\section{Socio-economic Impacts of Sea-level Rise in Kenitra Coast}

Sea level rise (SLR) and associated extreme water level events have many impacts on coastal systems including flooding, submergence, erosion and wetland change (Lin et al., 2013). This affects beaches, ecosystems, habitats, roads, and railways. These vital spaces maybe affected still more by the retreat of the coastline and by submersions

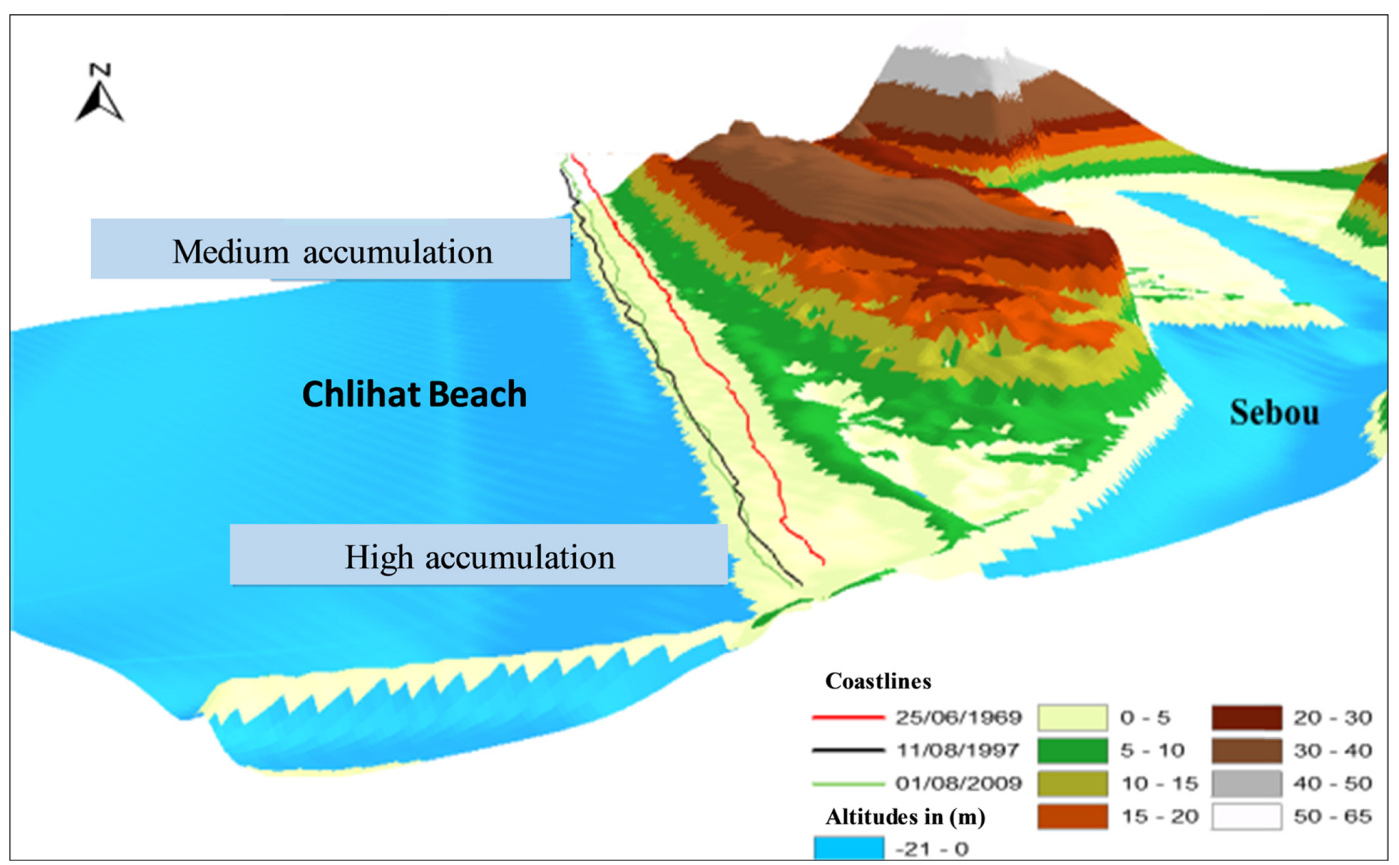

Figure 10. Evolution of the coastline in Chlihat Beach. 


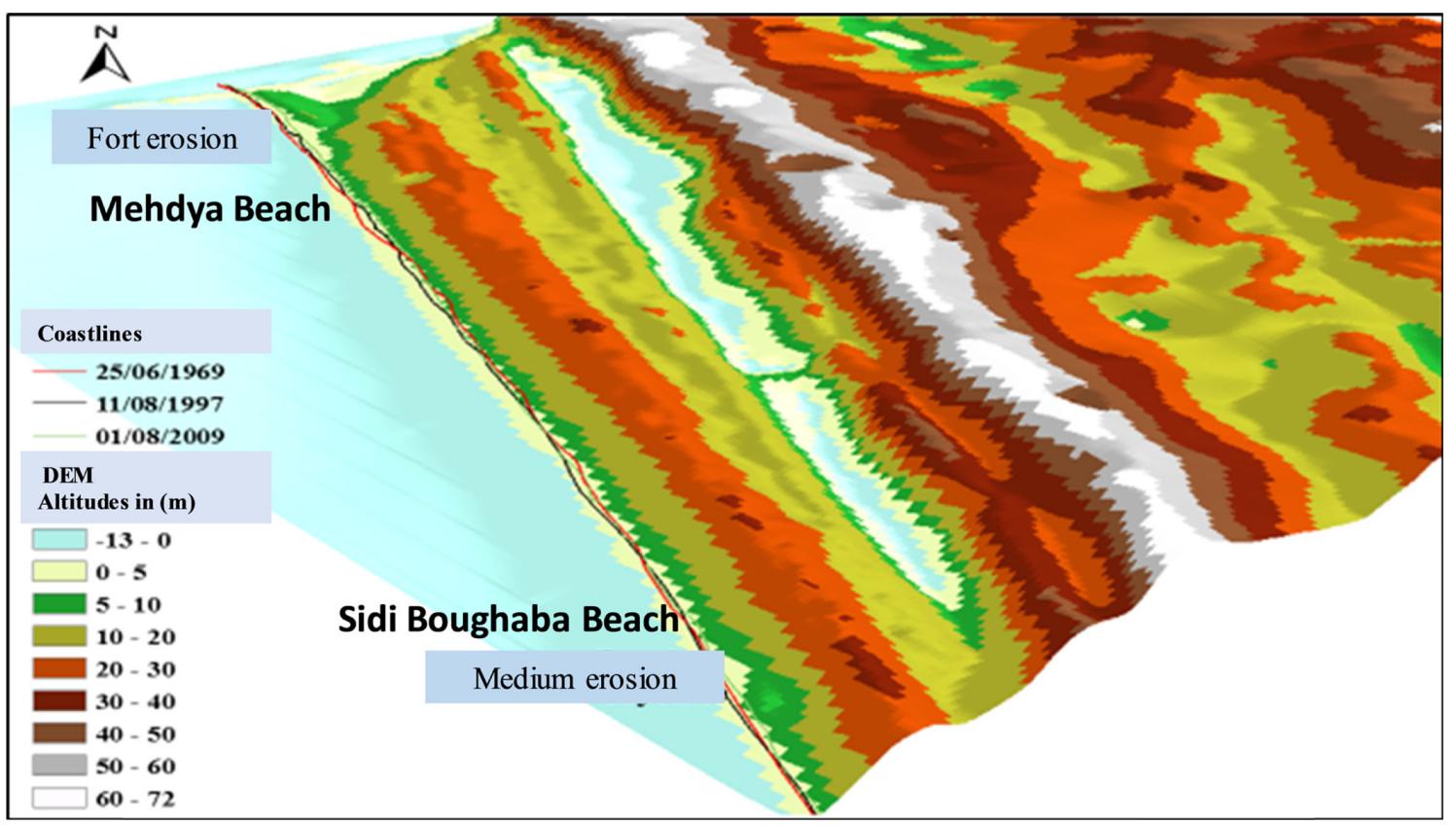

Figure 11. Evolution of the coastline in Mehdya Beach and Sidi Boughaba.

during the next century. These would be the most to be feared particularly of a conjunction of extreme events. They would cause enormous damage in areas at risk.

Parallel to the environmental impacts, the socio-economic damage would be all the more important as submersion would be progressive. In kenitra, the exposure of socio-economic stakes would be increasingly strong as the level of flood would be high.

Coastal ecosystems would be flooded, particularly those occupying topographically low areas. Thus, Sebou River and Sidi Boughaba Lake are in danger of being completely flooded by 2100 .

As for the Kenitra beaches, they would be moderately submerged, as rising sea levels will accelerate coastal erosion. Followed by tourism infrastructures located in mehdya beach.

The forest in chlihat beach, would be low threatened by an accelerated rise in sea level.

\section{Conclusions}

This study focuses on the projected inundation on the Kenitra coast, one of the most productive, but at the same time most susceptible to sea-level rise. The results obtained indicate that the most vulnerable areas to inundation are the low-lying lands of Kenitra where natural coastal defenses such as dunes have been destroyed in Mehdya Beach. Urban settlements, including tourist resorts, the coastal dunes and Beach, Mouth of the Sebou, Lake of Sidi-Boughaba would be the most affected economic sectors, followed by forests. These results draw attention towards the importance of upgrading awareness of decision-makers and planners to the potential future impacts of sea-level rise in this region.

In addition, the mobility feature of Kenitra coast over 40 years, from 1969 to 2009 shows that the study area has experienced two different evolutions. The coast recorded a fattening development north of the Sebou river and another marked by alternating areas of erosion and accretion zones in the South Bay of Sebou river. In this compartment, the sections that have suffered erosion are those of Mehdya and Sidi-Boughaba. With an erosion rate in Mehdya Beach and SidiBoughaba Beach is $(-2.39 \mathrm{~m} / \mathrm{year})$ and the progradation rate in Chlihat Beach is $(+1.96 \mathrm{~m} /$ year $)$.

Moreover, this evolution of erosion at the beaches of Mehdya and Sidi-Boughaba can be explained by this factors:

- Marine structures (Dike at the mouth of the Sebou),

- Dams (Al Wahda in 1996),

- Dredging of marine sand and a possible increase in the frequency and the intensity of ocean storms related to global changes which exposed coastline of the region given its location in a low plain.

\section{Acknowledgements}

The authors gratefully acknowledge Prof. Daekyo Cheong (Editor, Episodes Journal of International Geoscience) and two anonymous reviewers for their scientific suggestions and constructive comments.

\section{References}

Aberkan, M., 1989, Etude des formations quaternaires des marges du bassin du Rharb (Maroc nord occidental): Thèse, Université de Bordeaux I, Bordeaux, $290 \mathrm{p}$.

Aerts, J., Major, D.C., Bowman, M.J., Dircke, P., and Aris Marfai, M., 2009, Connecting Delta Cities: Coastal Cities, Flood Risk Management and Adaptation to Climate Change: Vrije Universiteit Press, Amsterdam, $91 \mathrm{p}$.

Aucelli, P.P.C., Di Paola, G., Incontri, P., Rizzo, A., Vilardo, G., Benassai, G., Buonocore, B, and Pappone, G., 2016, Coastal inundation risk assessment due to subsidence and sea level rise in a Mediterranean alluvial plain (Volturno coastal plain - southern Italy): Estuarine, Coastal and 
Shelf Science, v. 198, pp. 597-609.

Azidane, H., Benmohammadi, A., Haddout, S., Hakkou, M., Belrhaba, T., and Magrane, B., 2016, Evaluating the impacts of sea-level-rise on the Moroccan coast: quantifying coastal erosion and inundation in an Atlantic alluvial plain Kenitra coastal (abs): International Conference on Geospatial Technologies of Water Resources, On the Occasion of the COP22, Marrakech, Nov. 11-12.

Barbosa, P., 2004, Erosion risk levels at the NW Portuguese coast: The Douro mouth - Cape Mondego stretch, Journal of Coastal Conservation, v. 10 , no. 1 , pp. $43-52$.

Benmohammadi, A., Griboulard, R., Zourarah, B., Carruesco, C., Mehdi, K., Mridekh, A., El Moussaoui, A., Mhamdi Alaoui, M., Carbonel, P., and Londeix, L., 2007, Hyperactive neotectonic near the South Rifian frontlifted late Quaternary lagunal deposit (Atlantic Morocco): Comptes Rendus Geosciences, v. 339, no. 13, pp. 831-839.

Bouwer, L.M., Crompton, R.P., Faust, E., Höppe, P., and Pielke Jr, R.A., 2007, Confronting disaster losses: Science, v. 318, no. 5851, pp. 753.

Chatterjee, R.S., Fruneau, B., Rudant, J.P., Roy, P.S., Frison, P.-L., Lakhera, R.C., Dadhwal, V.K., and Saha, R., 2006, Subsidence of Kolkata (Calcutta) City, India during the 1990s as observed from space by differential synthetic aperture radar interferometry (D-InSAR) technique: Remote Sensing of Environment, v. 102, no. 1, pp. 176-185.

Dasgupta, S., Laplante, B., Meisner, C.M., Wheeler, D., and Jianping Yan, D., 2007, The impact of sea level rise on developing countries: a comparative analysis: World Bank, Policy Research Working Paper 4136. https://doi.org/10.1596/1813-9450-4136

Demirkesen, A.C., Evrendilek, F., and Berberoglu, S., 2008, Quantifying coastal inundation vulnerability of Turkey to sea-level rise: Environmental Monitoring and Assessment, v. 138, no. 1-3, pp. 101-106.

Ebrahim, G.Y., Jonoski, A., van Griensven, A., and Di Baldassarre, G., 2013, Downscaling technique uncertainty in assessing hydrological impact of climate change in the Upper Beles River Basin, Ethiopia: Hydrology Research, v. 44, no. 2, pp. 377-398.

Ericson, J.P., Vörösmarty, C.J., Dingman, S.L., Ward, L.G., and Meybeck, M., 2006, Effective sea-level rise and deltas: causes of change and human dimension implications: Global and Planetary Change, v. 50, no. 1 , pp. 63-82.

Hakkou, M., 2012, Contribution à l'étude de la dynamique morpho sédimentaire du littoral de Bouknadel - Kénitra: Thèse nationale, Université Ibn Tofail, Kénitra.

Hakkou, M., Castelle, B., Benmohammadi, A., and Zourara, B., 2010, Climat de houle et caractéristiques morpho-sédimentaires du littoral de Bouknadel-Kénitra (Maroc): XIème Journées Nationales Génie Côtier, Génie Civil Les Sables d'Olonne, Jun. 22-25, 2010.

Hakkou, M., Castelle, B., Benmohammadi, A., and Zourarah, B., 2011, Wave climate and morphosedimentary characteristics of the KenitraBouknadel sandy coast, Morocco: Environmental Earth Sciences, v. 64, no. 7, pp. 1729-1739.

Haddout, S., Maslouhi, A., Magrane, B., and Igouzal, M., 2016a, Study of salinity variation in the Sebou River Estuary (Morocco): Desalination and Water Treatment, v. 57, no. 36, pp. 17075-17086.

Haddout, S., Igouzal, M., and Maslouhi, A., 2016b, Analytical and numerical study of the salinity intrusion in the Sebou river estuary (Morocco) - effect of the "Super Blood Moon" (total lunar eclipse) of 2015: Hydrology and Earth System Sciences, v. 20, no. 9, pp. 3923-3945.

Haddout, S., Maslouhi, A., and Igouzal, M., 2017, Predicting of salt water intrusion in the Sebou river estuary (Morocco): Journal of Applied
Water Engineering and Research, v. 5, no. 1, pp. 40-50.

Hoozemans, F.M.J., Marchand, M., and Pennekamp, H.A., 1993, Sea Level Rise : A Global Vulnerability Assessment ( $2^{\text {nd }}$ edition): Delft Hydraulics, Delft, 184 p.

Idrissi, M., Ait Laamel, M., Hourimeche, A., and Chagdali, M., 2004, Impact of the swell on the current morphological and sedimentary evolution of the coastal zone of Casablanca-Mohammedia (Morocco): Journal of African Earth Sciences, v. 39, pp. 541-548.

IPCC, 2007, Climate Change 2007: The Physical Science Basis. Contribution of Working Group I to the Fourth Assessment Report of the Intergovernmental Panel on Climate Change: Cambridge University Press, Cambridge, $996 \mathrm{p}$.

IPCC, 2014, Climate Change 2014: Synthesis Report. Contribution of Working Groups I, II and III to the Fifth Assessment Report of the Intergovernmental Panel on Climate Change: IPCC, Geneva, 151 p.

Lin, B.B., Khoo, Y.B., Inman, M., Wang, C., Tapsuwan, S., and Wang, X., 2013, Assessing inundation damage and timing of adaptation: sea level rise and the complexities of land use in coastal communities: Mitigation and Adaptation Strategies for Global Change, v. 19, no. 5, pp. 551568.

Madouni, A., 1997, Géomorphologie et aménagement du littoral de Kenitra, de part et d'autre de l'estuaire du Sebou : Ph.D. Thesis, Université de Bretagne Occientale, Brest, 238 p. (in French)

Meckel, T.A., Ten Brink, U.S., and Williams, S.J., 2007, Sediment compaction rates and subsidence in deltaic plains: numerical constraints and stratigraphic influences: Basin Research, v. 19, no. 1, pp. 19-31.

Mhamdi Alaoui, A., Choura, M., Maanan, M., Zourarah, B., Robin, M., Freitas Conceição, M., Andrade, C., Khalid, M., and Carruesco, C., 2010, Metal fluxes to the sediments of the Moulay Bousselham lagoon, Morocco: Environmental Earth Sciences, v. 61, pp. 275-286.

Moussaid, J., Fora, A.A., Zourarah, B., Maanan, M., and Maanan, M., 2015, Using automatic computation to analyze the rate of shoreline change on the Kenitra coast, Morocco: Ocean Engineering, v. 102, pp. 71-77.

Musa, Z.N., Popescu, I., and Mynett, A., 2014, The Niger Delta's vulnerability to river floods due to sea level rise: Natural Hazards and Earth System Sciences, v. 14, no. 12, pp. 3317-3329.

Nicholls, R.J., 1995, Coastal megacities and climate change: Geo Journal, v. 37, no. 3, pp. 369-379.

Nicholls, R.J., 2004, Coastal flooding and wetland loss in the $21^{\text {st }}$ century: changes under the SRES climate and socio-economic scenarios: Global Environmental Change, v. 14, no. 1, pp. 69-86.

Nicholls, R.J., Hanson, S., Herweijer, C., Patmore, N., Hallegatte, S., Corfee-Morlot, J., and Muir-Wood, R., 2008, Ranking port cities with high exposure and vulnerability to climate extremes: exposure estimates: OECD Environment Working Papers, no. 1, 63 p.

Nicholls, R.J., Wong, P.P., Burkett, V.R., Codignotto, J.O., Hay, J.E., McLean, R.F., Ragoonaden, S., and Woodroffe, C.D., 2007, Coastal systems and low-lying areas. Climate Change 2007: Impacts, Adaptation and Vulnerability. Contribution of Working Group II to the Fourth Assessment Report of the Intergovernmental Panel on Climate Change: Cambridge University Press, Cambridge, pp. 315-356.

Peltier, W.R., 1998, Postglacial variations in the level of the sea: implications for climate dynamics and solid-earth geophysics: Reviews of Geophysics, v. 36, no. 4, pp. 603-689.

Snoussi, M., Ouchani, T., Khouakhi, A., and Niang-Diop, I., 2009, Impacts of sea-level rise on the Moroccan coastal zone: quantifying coastal erosion and flooding in the Tangier Bay: Geomorphology, v. 107, no. 1, pp. 32-40. 


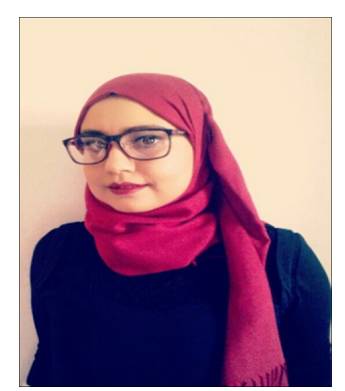

Azidane Hind is a Ph.D in the Department of Geology, Faculty of Science, Ibn tofail University, Morocco. His recent research interests concern marine geology and impact study, the technical exploration and exploitation of Georesources, Impact Assessment and Rehabilitation and sedimentological studies.

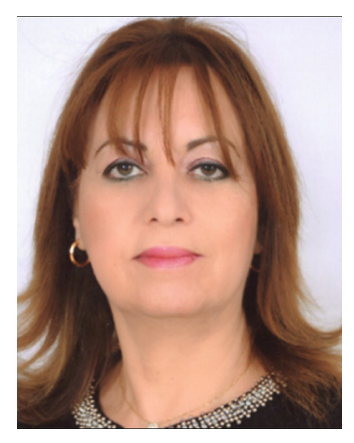

Benmohammadi Ä̈cha is working as a professor in the Department of Geology, Faculty of Science, Ibn tofail University, Morocco. His areas of expertise include: Sedimentology, Oceanography, littoral, environmental Geosciences and coastal protection. Director search in environmental geoscience and president of the Moroccan Association for the protection of the coast and sustainable development.

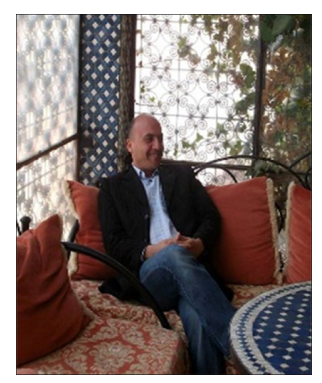

Hakkou Mounir is working as a professor in the Department of Geology, Faculty of Science, University Mohammed V in Rabat, Institut Scientifique, Morocco. His areas of expertise include coastal management and oceanography.

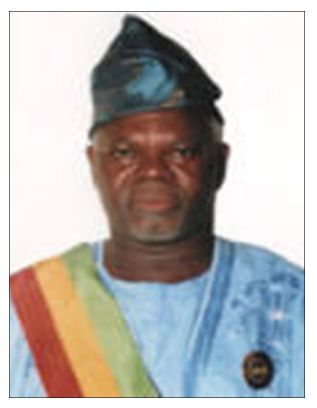

Michel Boko is working as a professor of Benin. Academician, Co-Nobel Peace Prize 2007. His areas of expertise include: Geography, Climatology and Environment. Commander of the National Order of Benin; Knight of the International Order of Palms; Academic of CAMES and High Counselor of the Republic (CES-Benin).

Belrhaba Tarik is a Ph.D. candidate in the Department of Geology, Faculty of Science, Ibn Tofail University, Morocco. His recent research interests concern climate change adaptation and sustainable development and natural hazards.

Magrane Bouchaib is a hydrogeologist state engineer Ministry of Energy, Mines, Water and Environment, Water Service of Kenitra City (Morocco). His areas of expertise include: management and water resources planning. it occupies the post of delegate hydrological basin agency of Sebou in Kenitra city. 